\title{
OUR PATCH VS. THEIR PATCH: INFORMATION TECHNOLOGY AND LITERACY IN SCHOOLS
}

\author{
Barbara Yates \\ Coordinator of Library Services \\ Barker College \\ Hornsby NSW 2077, Australia \\ E-mail: barbara_yates@barker.nsw.edu.au
}

\begin{abstract}
The information technology revolution is affecting schools on a broader basis than just libraries. Teachers, administrators and educational technology specialists are all espousing expanded roles to address the new opportunities with the result that responsibilities are beginning to overlap and roles are becoming blurred. In this paper the importance of defining a specific "patch" for the school librarian is stressed and criteria for the development of the "patch" are suggested.
\end{abstract}

\section{INTRODUCTION}

The use of increasingly generalized job profiles is blurring the role of the school librarian, particularly in relation to information technology or the use of computers.

\section{We Know Who We Are}

When school librarians meet to discuss emerging issues, such as information technology, we know the backgrounds and capabilities of each other. We have a fairly common understanding of what each of us does. We understand the contribution the school librarian can make. We know that, no matter how radical the discussion or the terms used, we will leave our meeting as school librarians - at least in the sense that we understand that we know who we are.

\section{Do They Know Who We Are?}

But when others, educational professionals and those who rely on our services, employers in particular, listen to the school librarians discussing these issues, they are often perplexed by the language used. They can be unsettled by the continual debate and uncertainty as to the future of information technology in education. They can be confused by the role of the librarian in this information age.

\section{Why Is It Important To Define Our Patch?}

The role of the school librarian is being challenged by data professionals from many walks of life. This paper explores this issue. If we do not endeavor to define our patch, then those that employ us will not define it for us. When they are challenged by the uncertainties of information technology, they will look to the support of information technology professionals-whoever they may be. This may not include us. Unless school librarians focus on distinguishing themselves in a value-added sense they may disappear from schools.

\section{How do we do it?}

How do we define our patch? We may look at what we really do and compare this to what other information professionals do. We might see if we can still distinguish our own patch, based on what we do. 


\section{How do we get the message across to others?}

Finally, if we can distinguish our patch, we might find a simple means of getting the message across to others. By "others," we mean those that we serve as well as those who will employ us.

\section{EXTERNAL PERCEPTIONS}

\section{How Do Others See Us?}

This paper is primarily concerned with the way others see us. There have been some radical views presented, particularly in relation to the school library in the future:

presented, particularly in relation to the school library in the future:

- the Library has been demolished and replaced by a cupboard containing a hub of small computing devices;

- the ancient crone, the Librarian, has disappeared forever;

- rotting vegetable matter, the book, has been destroyed;

- a single, digital network encircles the globe. (Perry, 1995)

\section{How Many Of Us Will Disappear?}

If this seems too far distant, consider contemporary advertisements from the major daily newspapers in Australia. A selection of six typical advertisements has been examined, illustrating the confusing terminology in this area; key points being summarized below.

\section{Federal Court of Australia - Director, Library and Information Services}

- leadership for the Library and Records Management function;

- harnessing technology to effectively support library services, information management and research services;

- budgeting, client services and team building;

- appropriate degree and library qualifications.

\section{HB Technology Manager}

- software company, customer service, strong services orientation;

- technology upgrade with ongoing support of new PC-based technology;

- no formal qualifications mentioned.

\section{Burwood CouncilComputer-Information Services Manager}

- computer and records management;

- budgeting, managing Council's computer and information systems;

- tertiary qualifications in a computer-related discipline desirable but not essential.

Human Rights and Equal Opportunity Commission-Library and Information Services Manager

- managing the library, information services, human resources; client services;

- future library services, strategies and technologies;

- appropriate degree and library qualifications.

\section{Campbelltown City Council - Library Information Technology Coordinator}

- coordinating information technology functions of the Library;

- IT customer services with close liaison with internal Information Technology Services;

- tertiary qualifications preferably in library and information science and/or IT;

- experience in library or information technology;

- customer-focused service;

- experience using and supporting Windows 95 and Microsoft Office;

- experience using an integrated library management system;

- shift work.

\section{Loreto Normanhurst-Information Services Coordinator}

- qualifications as a teacher/librarian or in Library Science and /or Information Technology; provide information access; 
- develop training programs, have management skills and human resource skills;

- engage with students in learning situations;

- assistant designer of the Information Resources Centre;

- manage the IRC and extended hours;

- report to Deputy Principal Curriculum and work with the IT Coordinator.

Table 1 illustrates some of the problems with the terminology by grouping the position titles under two broad headings, primarily library-focused vs. primarily computer-focused.

\begin{tabular}{|l|l|}
\hline \multicolumn{1}{|c|}{ LIB RARY FOCUSED } & \multicolumn{1}{|c|}{ COMPUTER FOCUSED } \\
\hline Co-ordinating Teacher/Librarian & Computer Coordinator \\
\hline Technology Librarian & $\begin{array}{l}\text { Technology Manager } \\
\text { Information Technology Manager }\end{array}$ \\
\hline $\begin{array}{l}\text { Co-ordinator of Library Services } \\
\text { of Library Services }\end{array}$ & Director \\
\hline $\begin{array}{l}\text { Information Services Manager } \\
\text { Heard of Information Services } \\
\text { Teacher, Information Services }\end{array}$ & Manager of Information Services \\
\hline Information Manager/Librarian & Information Services Co-ordinator \\
\hline Director, Library and Information Services & \\
\hline Director of Information Services & Director of Information Services \\
\hline
\end{tabular}

Table 1: Terminology of Position Title by Focus

The progression to increasingly generalized titles is immediately obvious. As well, the table shows:

- the words "services" and "information" creep into both lexicons;

- "computer" is replaced by "technology" and "information technology";

- "technology" is replaced by "services," to emphasize not technology-driven;

- "information" and "services" are generalized, with no specific meaning;

- there is a resultant blurring of roles.

A further examination of the advertisements leads to the following observations:

- Different requirements for qualifications in library science and information technology creep into the advertisements, although the jobs are similar. For example, the Loreto job asks for a teacher/librarian or library or information technology specialist, although the job requires a teaching component;

- The Federal Court and Human Rights Commission require a librarian focused on providing services, and skilled in management and budgeting and the use of IT as a tool for providing these services;

- The Campbelltown City Council wants a librarian, an IT service and support person for software, and a shift worker all rolled into one for AUS\$693.80 per week! To whom will the successful applicant report?;

- The Information Services Coordinator position at Loreto used to be the Teacher Librarian. Except for reference teacher/librarian or Library and Information Science, there is no mention of the library in the whole advertisement. What about "harnessing the technology" to provide a 
good service to the users? What about reading guidance to the bright students and the not-sobright? What about the team-teaching function? In fact, the terms "team" or "teaching" are not used at all in the advertisement.

In Australia, the school librarian is usually a Head of Department reporting directly to the principal. This job entails reading guidance, resource management and development (i.e., books, videos, kits, maps, pictures, CD-ROMs, newspaper clippings), budgetary control, teaching functions, and service to all clients. There could be a Year 7 boy looking for a "good" book to read, a Year 12 girl wanting a relevant critique of Keats, or a teaching colleague trying to find some information on quality in educational management for a Masters degree. Such requests can occur in the space of three minutes. Information technology has had a fantastic impact on making such service functions easier to achieve. So, out of the confusion, we must ensure that others see us for what we are and what we do.

\section{CLARIFYING OUR ROLE TO OTHERS}

If we find it difficult to understand and interpret the foregoing, it is little wonder that others are confused. We need to define our patch. We need to do this in a way that is simple and easily understood by others. We need to apply the following criteria for development of our patch- our reason for being:

Unique-we are unique in the school;

Understandable-colleagues must understand what we stand for;

Universally recognizable — colleagues must understand what we do; and

Reflects what we really do- our job description and title must reflect what we really do.

In Australia, the Aboriginal people have a concept of "place." They are not confused as to who they are, where they are going and why. The concept of place is of long-standing importance to mankind. So, we could build on the universal perception of what a library is. It is a "place." Everyone's concept of a library reflects a definable image. The word "library" from the Latin liber meaning "book" was defined long before books as we know them were developed. In fact, the original Roman word meant bark, as in tree bark. In 1374, Chaucer used the term library, predating the printing of the Gutenberg Bible by approximately a century. The library as "place" survived that technological revolution.

Perhaps we could do worse than resorting to our traditional labels. Perhaps we should simply call our patch a library. At least most people recognize the term and understand it. Perhaps we should simply call ourselves librarians. These terms are used universally to denote the type of place we work in and the type of work we do. But we know the work is changing. Let us be clear about our role in this work. Let us look at what we really do!

Table 2, (drawing from my own experience), includes an analysis of the key functions of the school librarian and the computer specialist. Table 2 illustrates some important points, as follows:

- the key function of the school librarian is to assist teachers to identify, access, evaluate and integrate information resources into their teaching /learning programs (In Australia, school librarians are required to have dual qualifications in librarianship and teaching to provide the appropriate educational support in the classroom.);

- the key function of the computer specialist is to coordinate network administration, mainframe development, systems installations, cabling, records management procedures, and to provide support services to the school;

- the computer specialist acts in a services-provider role for the school;

- there is little overlap, in a functional sense, between the school librarian and the computer specialist;

- It should be possible to define our patch based on what we do. 


\begin{tabular}{|l|c|c|}
\hline Key functions & $\begin{array}{l}\text { School } \\
\text { Librarian }\end{array}$ & $\begin{array}{c}\text { Computer } \\
\text { Specialist }\end{array}$ \\
\hline $\begin{array}{l}\text { Assiste teachers to identify, access, evaluate and integrate } \\
\text { information resources into their teaching/ learning programs }\end{array}$ & $\mathrm{X}$ & \\
\hline Provides reading guidance and encourages reading experiences. & $\mathrm{X}$ & \\
\hline $\begin{array}{l}\text { Plans, develops, organizes, manages, stores and circulates } \\
\text { information resources (books, serials, audiovisual, CD-ROMs) in } \\
\text { the school meeting all curriculum needs outcomes }\end{array}$ & $\mathrm{X}$ & \\
\hline $\begin{array}{l}\text { Trains and assists students and teachers to locate appreopriate } \\
\text { resources, intramural and extra-mural }\end{array}$ & $\mathrm{X}$ & \\
\hline $\begin{array}{l}\text { Identifies and retrives information form resources beyond the } \\
\text { school using personal contact, telephone, fax, letter, and } \\
\text { computers (including Internet). }\end{array}$ & $\mathrm{X}$ & $\mathrm{X}$ \\
\hline User specification of library computer systems. & $\mathrm{X}$ \\
\hline $\begin{array}{l}\text { Administers and coordinates, networks, mainframe development, } \\
\text { systems installations, cabling, records management procedures } \\
\text { and technologies; provides support services to all school } \\
\text { departments for operation and maintenance of computer } \\
\text { resources. }\end{array}$ & & $\mathrm{X}$ \\
\hline $\begin{array}{l}\text { Copordinates computer resources throughout the school. } \\
\text { Initiates, evaluates and specifies future computer systems. }\end{array}$ & & $\mathrm{X}$ \\
\hline Ensures computer users follow regular security procedures. & & \\
\hline
\end{tabular}

Tabel 2: Key Functions of the School Librarian and the Computer Specialist

\section{GETTING THE MESSAGE ACROSS}

\section{Describing Our Patch To Others}

In describing our patch in a way that will be understood by others, school librarians must avoid acronyms, and library-specific terms and statements (jargon). We must carefully state our direction and purpose to avoid merely drifting along to some undefined destination. Otherwise, others will be steering our course for us. In describing our patch to others we must:

- emphasize what we really do in job descriptions and advertisements;

- emphasize what we really do when we meet with others outside our profession e.g. at conferences;

- contribute to school strategy and planning in terms of our real skills;

- develop and publicizing a mission statement.

There is continued debate about what constitutes a vision statement and a mission statement. When developing these statements, the school librarian should look to the statements of the parent body. The vision statement and school philosophy of Barker College are included as Figure 1 by way of example. 


\section{Barker College Vision}

That Barker College will be recognized as a leading Australian Christian independent school which provides a broadly-based education and encourages young people to strive for excellence.

\section{School Philosophy}

Barker College provides education within a caring, ordered Christian family environment:

- where the Christian values and Anglican traditions of the College are maintained;

- where each member of the College community is affirmed, valued and challenged;

- where students and staff are encouraged to strive for excellence in all areas of endeavour to the best of their ability; and

- where young people are prepared for active and responsible participation in the community.

Figure 1: Vision and School Philosophy of Barker College.

The library's mission statement follows from the school's vision statement and has been approved by the Head of Barker College. It includes a concrete, attainable and understandable set of parameters for the library in the context of the overall school vision and philosophy as shown in Figure 2.

\section{Mission of the Barker College Library}

The mission of the Barker College Library is to encourage and support the educational programs of Barker College by providing access to recorded knowledge through the acquisition, organization, preservation and interpretation of information appropriate to the needs of the students and staff served by the library at Barker College.

The mission statement reflects what we do in the library:

- we support the educational program;

- we provide access to information for our clients;

- we organize that information for retrieval;

- we obtain and preserve that information for anticipated need;

- we serve both categories of clients, both staff and students.

How we do this is what makes us librarians. We may use the telephone, the fax, the photocopier, the television, and the Internet. We may know someone within our network of contacts-from our area professional meetings, from parents, from our family, from special events-who can help us find exactly what our client needs. Such needs vary from client to client, from classroom to classroom, from school to school.

Figure 2: Mission of Barker College Library 


\section{CONCLUSION}

The role of the librarian, whether it be in a school, a company, or a government department has not changed. "How we do it" has changed . Librarians must embrace the new methods of accessing information but they must not be subsumed by them. Our role is to add value to the information process to make it relevant. We need to be clear about our role and we need to get the message across to others. We should not be preparing to disappear!

And, on this note, the final word goes to Vint Serf, the "Father of the Internet," speaking in Sydney in early 1997:

People need much more focused and more organized information. It's fun to go Web-surfing and [search] tools help considerably. But when you are looking for a particular thing, it would be helpful if we had more organized views of content.

Right now I am relying on the librarians and their 2,000 years of experience trying to organize information. They were all worried that they would have no jobs to do because computers would take over. I beg to differ: I think we need them now more than we ever did because of the vast quantity of material that needs to be more thoughtfully organized (Tebbut, 1997)

\section{REFERENCES}

Levy, C. D. (1997, March). Vision, mission and values: the keys to corporate success. Management, $17-19$.

Macquarie Dictionary (Rev. ed.). (1985). Sydney: Macquarie Library.

New Encyclopaedia Britannica (15th ed.) (1994). Cambridge: Cambridge University Press.

Nimon, M. (1996) Co-operative planning and teaching: A collaborative model for the 21st century: A point of view. In L. Hay \& J. Henri (Eds.), A meeting of minds: ITEC virtual conference 1996 (pp. 195-197 ). Australian School Library Association.

Oxford English Dictionary (1989 ed.). London: Clarendon.

Perry, M. (1995). Library Resource Centre Booklet. John Paul College.

Tebbut, D. (1997, January). Father of the Internet. Australian Personal Computer, 91-93. 